\title{
Aging and retinoid $\mathrm{X}$ receptor agonists on masculinization of female Pomacea canaliculata, with a critical appraisal of imposex evaluation in the Ampullariidae
}

\author{
Maximiliano Giraud-Billoud ${ }^{\mathrm{a}, \mathrm{b}, *}$, Alfredo Castro-Vazquez ${ }^{\mathrm{a}, \mathrm{b}, \mathrm{c}}$ \\ a IHEM, Universidad Nacional de Cuyo, CONICET, Casilla de Correo 33, 5500-Mendoza, Argentina \\ ${ }^{\mathrm{b}}$ Universidad Nacional de Cuyo, Facultad de Ciencias Médicas, Instituto de Fisiología, Casilla de Correo 33, 5500-Mendoza, Argentina \\ ${ }^{\mathrm{c}}$ Universidad Nacional de Cuyo, Facultad de Ciencias Exactas y Naturales, Departamento de Biología, Casilla de Correo 33, 5500-Mendoza, Argentina
}

\section{A R T I C L E I N F O}

\section{Keywords:}

Gastropod

Copulatory apparatus

Organotins

RXR signaling

PPAR signaling

\begin{abstract}
A B S T R A C T
Ampullariidae are unique among gastropods in that females normally show a primordium of the copulatory apparatus (CApp). The aims of this study were (a) to quantitatively evaluate the development and growth of the female CApp with age; (b) to compare the effects of RXR and PPAR $\gamma$ agonists in adult females of known age and (c) to explore the effect of masculinizing RXR agonists on the expression of RXR in the CApp. It was found that the CApp grows and develops with age. A significant increase in penile sheath length (PsL) and also in a developmental index (DI) was observed in 7-8 months old females, as compared with 4-5 months old ones. A reported endogenous agonist of RXR, 9-cis retinoic acid (9cis-RA), as well as two organotin compounds, tributyltin (TBT) and triphenyltin (TPT) which have been also reported to bind to RXR, were injected and its masculinizing effects were measured. Also, the effect of a PPAR $\gamma$ agonist, rosiglitazone, was studied. All studied RXR agonists, but not the PPAR $\gamma$ agonist, were effective in increasing PsL, penile length (PL) and DI. Finally, the expression of the RXR in the CApp was studied (Western blot) in control, TBT, TPT, and 9cis-RA treated females. A significantly increased expression of RXR was only observed after 9cis-RA treatment. It is concluded that (a) development and growth of the CApp is significantly affected by female age; (b) reported RXR agonists, but not a $\operatorname{PPAR} \gamma$ agonist, cause female masculinization of young females. An appraisal of previous studies of female masculinization in the Ampullariidae has also been made and it is emphasized that the masculinizing effect of aging should be considered, particularly when interpreting field data.
\end{abstract}

\section{Introduction}

Masculinization of female gastropods by tributyltin (TBT) and triphenyltin (TPT), has been mainly studied in the clades Neogastropoda, Littorinimorpha and Vetigastropoda (Shi et al., 2005; Titley-O'Neal et al., 2011), where the male penis develops as an outgrowth of the right side of the neck (Hyman, 1967). In these masculinized females, a vas deferens distal to the vaginal orifice and one or more penises may arise in the neck region, in which they do not correspond to any morphologically distinct primordium. The tissue outgrowth may also obstruct the genital tract (Gibbs et al., 1987), rendering the female sterile (see Titley-O'Neal et al., 2011, for more references).

On the contrary, adult females in the family Ampullariidae
(Architaenioglossa, sensu Bouchet and Rocroi, 2005) normally show a rudimentary 'copulatory apparatus' (CApp) in a small region between the anal papilla and the anterior end of the gill, which is also able to develop further in response to TBT, though no blockade of the female tract follows (Giraud-Billoud et al., 2013; Schulte-Oehlmann et al., 1995, 1994). The existence of these male-like structures in normal females was first noticed by Semper (1862) and later confirmed by numerous authors (Aboul-Ela and Beddiny, 1970; Andrews, 1964; Berthold, 1989, 1991; Bouvier, 1888; Gamarra-Luques et al., 2013; Gand, 1896; Hägler, 1923; Hylton-Scott, 1958; Prashad, 1925; Sachwatkin, 1920; Schulte-Oehlmann et al., 1994; Thiengo, 1987, 1989; Thiengo et al., 1993). In adult female Pomacea canaliculata (Lamarck 1822, Ampullariidae), these structures may sometimes develop

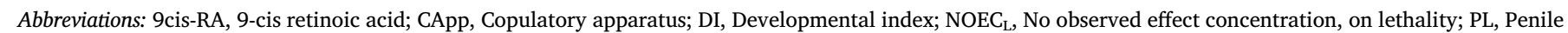

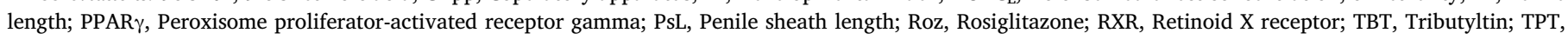
Triphenyltin; VDSI, Vas deferens sequence index

* Corresponding author at: Fisiología, IHEM-CONICET, Casilla de Correo 33, 5500 Mendoza, Argentina.

E-mail address: mgiraudbilloud@gmail.com (M. Giraud-Billoud). 
as a minute but complete CApp, including a coiled penis within a pouch, a muscular penile bulb and a penile sheath (with a penile sheath groove, a 'T-sulcus', and both distal and medial glands) (GamarraLuques et al., 2013).

Both TBT and TPT have been widely used as biocides (Horiguchi, 2016) and they still are (Takao, 2017), in spite of national and international banns (e.g., IMO, 2000; PNA, 1998). The main use of TBT is as a component of antifouling boat paints, while TPT is mainly used in agriculture (Greene, 2013; WHO, 1999) and both organotins have also been used against $P$. canaliculata in rice fields (Cheng and Kao, 2006). In this species, the NOEC $\mathrm{L}$ of TBT has been reported to promote CApp growth and development under properly controlled conditions (GiraudBilloud et al., 2013). Similarly, a masculinizing effect of TPT has been reported in Marisa cornuarietis, another ampullariid species (SchulteOehlmann et al., 2000).

A significant breakthrough in the molecular mechanisms underlying female masculinization in gastropods came from the study of Nishikawa et al. (2004) linking the action of organotins to activation of the retinoid X receptor (RXR) in Reishia (as Thais) clavigera (Neogastropoda, Muricidae). Other studies on the same and other neogastropod species (Nucella lapillus, Muricidae, and Tritia reticulata (as Nassarius reticulatus, Nassariidae) have followed (Castro et al., 2007; Horiguchi et al., 2007, 2010, 2008; Nishikawa et al., 2004; Sousa et al., 2010; Stange et al., 2012). Also, Pascoal et al. (2013) linked organotin action to activation of the peroxisome proliferator-activated gamma receptor (PPAR $\gamma$ ) in $N$. lapillus. However, no studies of the role of the RXR or PPAR signaling pathways have been reported for the Ampullariidae.

The present study on $P$. canaliculata includes: (1) the definition of a developmental index (DI) adapted to the peculiarities of the female CApp in the Ampullariidae; (2) a quantitative evaluation of development of the female CApp with age, in sexually mature snails; (3) the comparative effects of RXR and PPAR $\gamma$ agonists in adult females of known age; (4) the effect of masculinizing agonists in this species on the expression of RXR receptor in the female CApp. Also, a critical appraisal of female masculinization in the Ampullariidae is discussed.

\section{Material and methods}

\subsection{Animals and sacrifice}

Females of known age from a cultured strain of $P$. canaliculata were used. The original stock was collected at Rosedal lake, Palermo, Buenos Aires, Argentina, which is the neotype locality of the species (Hayes et al., 2012). Voucher (ethanol preserved) specimens of the original population and of the cultured strain were deposited at the collection of Museo Argentino de Ciencias Naturales (Buenos Aires, Argentina; lots MACN-In 35707 and MACN-In 36046). The culturing conditions have been described elsewhere (Giraud-Billoud et al., 2011). The animals were maintained during the experiments in $20 \mathrm{~cm} \mathrm{x} 38 \mathrm{~cm} \times 52 \mathrm{~cm}$ aquaria, were fed ad libitum with a mixed diet and water was changed three times a week. Room temperature was regulated at $24-26^{\circ} \mathrm{C}$ and artificial lighting was provided $14 \mathrm{~h}$ per day. Before shell cracking, females were immersed in water at $4{ }^{\circ} \mathrm{C}$ for $20-30 \mathrm{~min}$, for both relaxation and minimizing pain. All measurements were made with a caliper on fresh material, to the nearest $0.5 \mathrm{~mm}$.

\subsection{Chemical compounds used}

TBT chloride, TPT chloride, 9-cis-retinoic acid (9cis-RA) and rosiglitazone (Roz) were from Sigma-Aldrich (T50202; Aldrich 245712; R4643; R2408, respectively). The antibodies used were a rabbit polyclonal antibody against Retinoid X Receptor (RXR $\Delta$ N 197: sc-774, Santa Cruz Biotechnology), a mouse monoclonal anti- $\beta$-tubulin (SigmaAldrich, T4026) and peroxidase-conjugated goat anti-rabbit and antimouse IgG antibodies (Jackson ImmunoResearch).

\subsection{Scanning electron microscopy}

Representative cases of different stages of development of both control and TBT-treated females (4-6 months old) were fixed in Railliet-Henry's fluid and were serially dehydrated in ethanol, passed through acetone and then critical point dried, mounted on aluminum stubs, coated with gold, and examined with a LEO 1450VP scanning electron microscope.

\subsection{Light microscopy}

Tissue samples containing the CApp from adult females were dissected out and fixed in $4 \%$ paraformaldehyde solution and subsequently dehydrated and embedded in a resin-paraffin mixture (Histoplast ${ }^{\circledR}$ ), and serial section $(5 \mu \mathrm{m})$ stained with Harris hematoxylin and eosin were examined and photographed under a Nikon Eclipse 80i Microscope using Nikon DS-Fi1-U3 camera and Nikon NIS-ELEMENT Image Software for image acquisition.

\subsection{Quantitative assessment of the development of the female CApp}

The penis and penile sheath lengths were measured. For measuring, the penis had to be everted with a fine forceps through the opening of the penile pouch and stretched. In those particular cases in which a penis was found but was too short to measure, a length of $0.5 \mathrm{~mm}$ was arbitrarily attributed. Also, the presence or not of the basal, medial and distal glands and of the so-called T-sulcus (Gamarra-Luques et al., 2013, 2006) in the penile sheath were recorded, as well as the degree of development of the penile pouch and the penile bulb. With this information, a 'developmental index' (DI, different from the vas deferens sequence index, or VDSI, used in other gastropod species) was used here for expressing the mean masculinization degree of the CApp (see also Results and Discussion).

\subsection{Experimental sets}

\subsubsection{Development of the female CApp after sexual maturity}

Sexual maturity (as indicated by the first oviposition) occurs in our culturing conditions when the females are about 50 days old (GamarraLuques et al., 2013). Mature females aged 3, 4, 5, 6 and 7 months old, were separated in aquaria containing 7 females each. Thirty days later, the animals were sacrificed as described above (i.e., when being 4, 5, 6, 7 or 8 months old). After shell cracking, the roof of the mantle cavity was opened and the CApp was inspected under a stereoscopic microscope and the length of the penis and penile sheath were measured and the DI (see 3.1) was determined.

\subsubsection{Effects of injected TBT, TPT, 9cis-RA, and Roz on the development of the female CApp}

These compounds were injected in the foot of females aged 4 months old. The dose used was $1 \mu \mathrm{g} / \mathrm{g}$ of drained body mass of TBT and TPT (Horiguchi et al., 2008; Nishikawa et al., 2004), 1 or $2 \mu \mathrm{g} / \mathrm{g}$ of 9cisRA (Horiguchi et al., 2008; Sousa et al., 2010; Stange et al., 2012), and 2 or $4 \mu \mathrm{g} / \mathrm{g}$ of Roz (cf. Pascoal et al., 2013). Treated animals and their respective vehicle-injected controls were sacrificed 15 or 30 days after the injection. The vehicles used ( $2 \mu \mathrm{L}$ per dose) were: (1) a buffer solution (43 mM NaCl, $1.8 \mathrm{mM} \mathrm{KCl,} 10 \mathrm{mM}$ HEPES; pH 7.6; Cueto et al., 2015), to which TBT or TPT were added in ethanol to a final ethanol concentration of $0.001 \%$, (2) undiluted fetal calf serum for 9cis-RA, and (3) dimethylsulfoxide for Roz. Penile length, penile sheath length and developmental index of the female CApp were assessed at sacrifice. The number of cases per group (including the control groups, which were injected with the vehicles) was 10-12 for TBT, 8-13 for TPT and 9-11 for 9cis-RA and Roz. 


\subsection{Regulation of RXR expression in the female CApp}

Five groups of 4-months old females were injected with either the vehicles or $1 \mu \mathrm{g} / \mathrm{g}$ drained body mass of TBT, TPT or 9cis-RA (masculinizing compounds according to 2.6.2). The CApp was dissected out $2 \mathrm{~h}$ after the injection and 8 pools (4 apparatuses each, approximately $20 \mathrm{mg}$ of tissue) were placed in an ice-cold extraction buffer $(250 \mathrm{mM}$ sucrose, $20 \mathrm{mM}$ Tris-HCl, $5 \mathrm{mM}$ EDTA, $1 \mathrm{mM}$ dithioerythritol, $\mathrm{pH}$ 7.4) and were homogenized with an UltraTurrax ${ }^{\circledR}$ homogenizer. Kidney samples ('posterior kidney' in Andrews, 1965) were used as controls. The homogenates were mixed with a lysis buffer $(50 \mathrm{mM}$ Tris- $\mathrm{HCl}$, $25 \mathrm{mM}$ ClNa, $0.5 \%$ Triton, $1 \mathrm{mM}$ dithioerythritol, $\mathrm{pH}$ 7.4) and centrifuged at $10,500 \mathrm{~g}$ for $10 \mathrm{~min}$ at $4^{\circ} \mathrm{C}$. Then, the supernatants were aliquoted and kept at $-80^{\circ} \mathrm{C}$ until protein quantification (Lowry et al., 1951) and further processing.

Supernatant samples containing $25 \mu \mathrm{g}$ of protein were resolved by SDS-PAGE electrophoresis (4-10\% acrylamide-bisacrylamide), for $120 \mathrm{~min}$ at $100 \mathrm{~V}$, transferred onto a $0.2 \mu \mathrm{m}$ nitrocellulose membrane (GE Healthcare Amersham, UK) for $90 \mathrm{~min}$ at $90 \mathrm{~V}$. After that, the membrane was blocked for $1 \mathrm{~h}$ in TBS-T blocking buffer $\left(20 \mathrm{mmol}^{-1}\right.$ Tris-HCl, $140 \mathrm{mmol}^{-1} \mathrm{NaCl}, \mathrm{pH} 7.6$ and 5\% nonfat dry skim milk) and was incubated overnight at $4{ }^{\circ} \mathrm{C}$ with each of the primary antibodies against retinoid $\mathrm{X}$ receptor and $\beta$-tubulin, diluted 1:500 in TBS-T. Both secondary antibodies were diluted 1:5000 in TBS-T, and the bound antibody was then detected using enhanced chemiluminescence (GE Healthcare) and a gel analyzer (LAS-4000 Luminescent Image Analyzer, Fujifilm Life Science, Stamford, CT, USA). Densitometric semiquantification of the proteins' bands was done using NIH image analysis software (ImageJ, National Institutes of Health, Bethesda, MD, USA). Prestained molecular mass markers (161-0374, Precision Plus Protein Dual Color Standards, Bio-Rad, Hercules, CA, USA), were used to determine protein migration onto the gel.

Tissue expression levels of RXR were semi-quantified by dividing the density of the obtained band by that of the $\beta$-tubulin band, which was used as loading control, to normalize the variation among immunoblots. Results were expressed as means \pm S.E.M. of RXR $/ \beta$-tubulin relative density units (RDU).

\subsection{Statistical analyses}

The Gaussian distribution of variables and the homogeneity of variances were first evaluated, using Kolmogorov-Smirnov's and Bartlett's tests, respectively (Prism ${ }^{\circledast}$ 5.0). According to this, KruskalWallis one-way ANOVA followed by the Dunn's test (Prism ${ }^{\circledast} 5.0$ ) were used for multigroup comparisons, except for the RXR expression experiment, in which parametric one-way ANOVA and the Tukey's test were used. Significance level was fixed at $\mathrm{P}<0.05$.

\section{Results}

\subsection{Definition of DI}

A DI suitable for use in $P$. canaliculata was defined as a set of mutually exclusive categories, or 'stages', as follows (representative cases of each of these stages are shown in Fig. 1 under scanning electron microscopy):

Stage 1 (Fig. 1A), females showing a penile sheath rudiment with or without a rudimentary distal gland, and a small penile pouch containing a penis too short to be everted from the penile pouch;

Stage 2 (Fig. 1B), females showing distinct distal and medial glands on the penile sheath rudiment, and a penis which could be everted from the pouch, but sometimes was too short to be accurately measured;

Stage 3 (Fig. 1C), females showing a penile sheath rudiment with distal and medial glands and a penile sheath groove with a T-sulcus, also in which a coiled penis was seen by transparency within the penile pouch.
Since all the studied females showed some development of a CApp, a Stage 0 was not defined. For statistical comparisons, a score of 1,2 or 3 was attributed to the corresponding developmental stages.

It should be noted that some TBT-treated females in stage 3 showed an impressive development of the whole apparatus (Fig. 1D), to a degree which was not observed in control females.

Another feature of the female CApp of $P$. canaliculata was additionally explored because Schulte-Oehlmann et al., $(1995,1994)$ have described a 'vas deferens papilla' in another ampullariid species ( $M$. cornuarietis), whose development became a key feature for their evaluation of female masculinization in this species. This structure, however, had not been mentioned in previous reports of the female CApp in $P$. canaliculata (see quotations in the Introduction). Therefore, the occurrence of this structure in $P$. canaliculata was carefully explored. In fact, a papilla seemingly homologous to that described by SchulteOehlmann et al. $(1995,1994)$, was also found in several P. canaliculata individuals observed under SEM (Fig. 1A, C, and D), and it was also found in all semi-serially sectioned apparatuses. It is an outgrowth of the base of the penile bulb, close to the opening of the penile duct (Fig. 2), and since a distal vas deferens does not occur in the Ampullariidae (see Discussion, 4.1.), it is here referred to as the 'penile complex papilla' (Fig. 1). This papilla is small in P. canaliculata and is located in a groove between the penile complex and the anal papilla, space frequently filled with mucus and cellular debris (Fig. 2) and it may not be apparent under the stereoscopic microscope. Indeed, the fact that may be partly or totally hidden in this groove should explain why was not adverted in previous studies (e.g., Gamarra-Luques et al., 2013; Liu et al., 2006; Wu et al., 2010). Also, because it may be observed since the 'stage 1' defined above (Fig., 1A), it was not considered a useful character to evaluate female masculinization in $P$. canaliculata.

\subsection{Quantitative evaluation of development of the CApp in control females at different ages}

The increase with age of the DI and the length of the penis and the penile sheath is shown in Fig. 3 (for detailed data see Table 1 from supplementary material), with the lowest values observed between 4 and 5 months of age and the highest values between 7 and 8 months of age. There were statistically significant changes with age in the DI and the penile sheath length, but not in the penile length, whose changes showed a high variability (Kruskal-Wallis, Dunn test).

\subsection{Evaluation of the effects of injected TBT, TPT, 9cis-RA and Roz on development of the female CApp}

Fig. 4 shows the effects of TBT (upper panel) and TPT (lower panel), 15 and 30 days after injection to 4-months old females (for detailed data see Table 2 from Supplementary material). A rather large increase (about three-fold) in the length of the penis and of the penile sheath followed TBT treatment $(1 \mu \mathrm{g} / \mathrm{g})$ and the differences were statistically significant. However, these values remained uniformly high between 15 or 30 days after treatment (i.e., no significant differences were found between both days). The DI was also significantly increased on both days after treatment, and again, no significant differences were found between both days.

The injection of TPT ( $1 \mu \mathrm{g} / \mathrm{g})$ was followed by a statistically significant increase in penile length (also a three-fold increase) and penile sheath length, both 15 and 30 days after treatment. The DI was significantly increased 15 days but not 30 days after treatment (KruskalWallis, Dunn test).

Fig. 5 shows the effects of two doses of 9cis-RA ( 1 and $2 \mu \mathrm{g} / \mathrm{g}$ ), 15 and 30 days after single injections to 4-months old females. This RXR agonist-induced 5-6 fold increases in penile length and penile sheath length and the differences were statistically significant (Kruskal-Wallis, Dunn test). The DI was also significantly increased on both 15 and 30 days after treatment. 


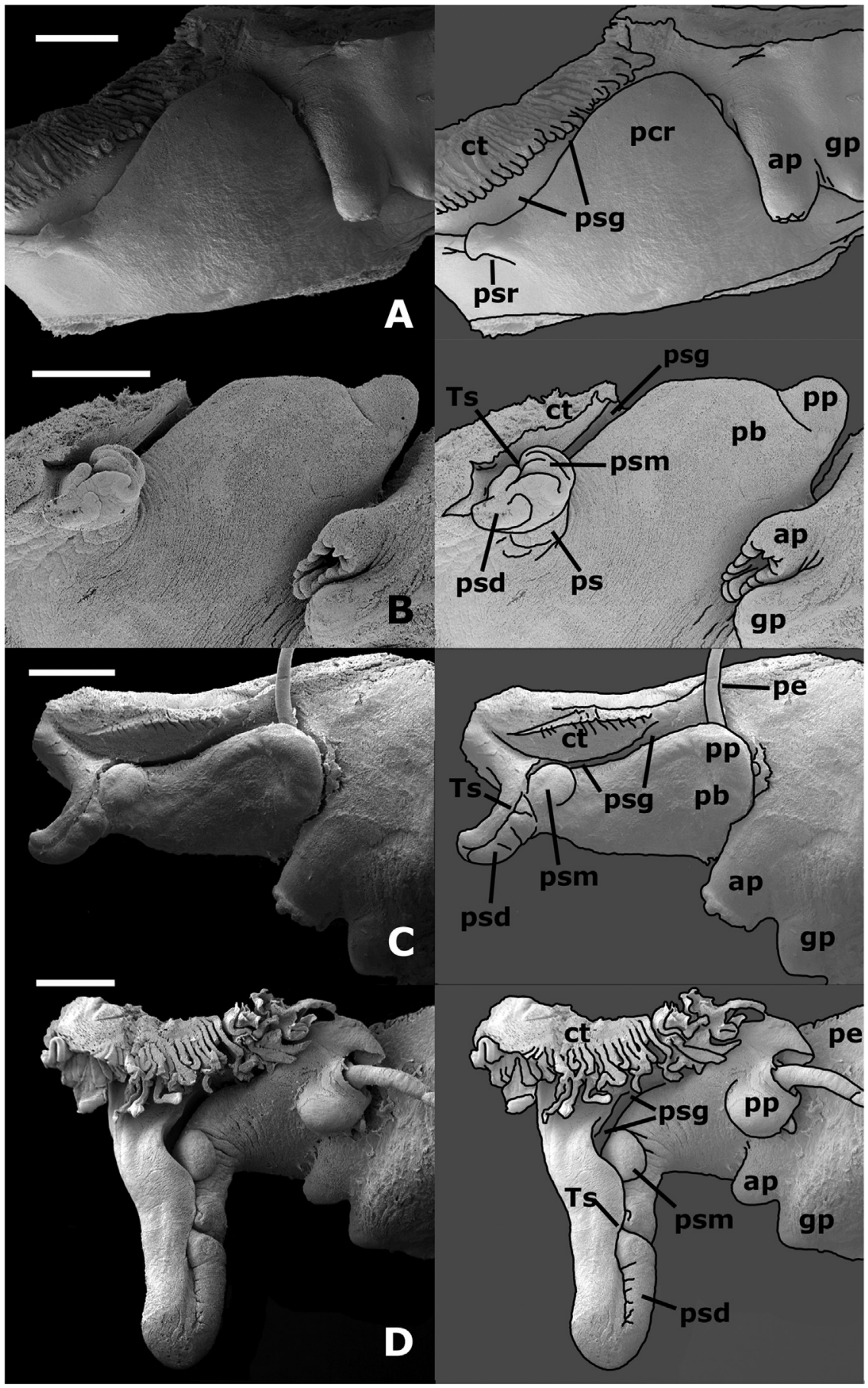

Fig. 1. Development of the female CApp in P. canaliculata rated according to a scale of mutually exclusive stages ('developmental index', DI). Panels A-C corresponds to control females, while panel D corresponds to a TBTtreated female. A. $\mathrm{DI}=1$, the penile complex rudiment is a flattened dome between the ctenidium and the anal papilla, while the penile sheath has grown as a small tubercle in the vicinity of the mantle edge. $\mathbf{B}$. $\mathrm{DI}=2$, the penile complex rudiment has differentiated into the penile pouch, which contains the threaded penis, and the penile sheath has enlarged as a short and blunted column, which has developed the medial and distal glands. C. DI $=3$, the penis has enlarged and can be easily extended out of the pouch with fine forceps; the penile sheath has become a miniature of that of the adult male. $\mathrm{D}$. $\mathrm{DI}=3$, in a TBTtreated female, showing an extreme development of the CApp. Abbreviations: ap, anal papilla; gp, genital papilla; p, penis; pb, penile bulb; pcp, penile complex papilla; pcr, penile complex rudiment; pp, penile pouch; ps, penile sheath; psd, penile sheath distal gland; psg, penile sheath groove; psm, penile sheath medial gland; psr, penile sheath rudiment; Ts, "T" sulcus. Bars $=1 \mathrm{~mm}$.

Notwithstanding, Roz (a PPAR $\gamma$ agonist) was ineffective, at two dose levels ( 2 and $4 \mu \mathrm{g} / \mathrm{g}$ ), to induce any change in the CApp, either 15 or 30 days after treatment (for detailed data see Table 2, Supplementary material).

\subsection{Regulation of RXR expression in the female CApp}

The expression of the RXR was studied by Western blot in extracts of the CApp and the kidney of control and treated females. Fig. 6 shows that the expression was significantly increased in CApps from females exposed to 9cis-RA, and also a smaller but non-significant increase was observed after TBT treatment. Treatments did not induce any significant change in the kidney expression of the RXR (RXR/ß-tubulin RDUs, vehicle: $1.04 \pm 0.13$; ТВT: $1.27 \pm 0.11$; TPT: $0.91 \pm 0.21$;
9cis-RA: $1.48 \pm 0.18)$.

\section{Discussion}

4.1. The use of the 'vas deferens sequence index' (VDSI) in the Ampullariidae

Different adaptations of the 'vas deferens sequence index' (VDSI) have been applied to three ampullariid species: $M$. cornuarietis (SchulteOehlmann et al., 1995, 1994), P. canaliculata (Liu et al., 2006; Wu et al., 2010) and Pomacea scalaris (Liu et al., 2006).

The VDSI was initially defined for $N$. lapillus (Neogastropoda) (Gibbs et al., 1987) and it has been modified several times for applying to other neogastropods and to representatives of the Vetigastropoda and 


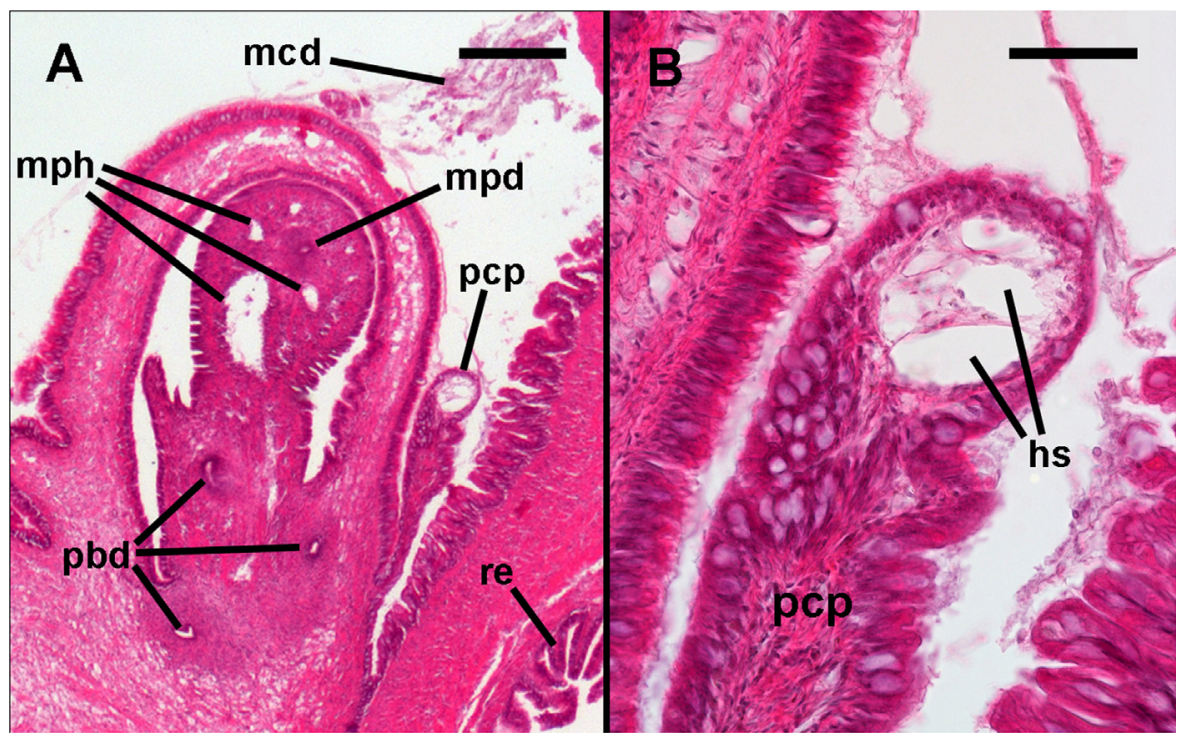

Fig. 2. The penile complex papilla. A. Section through the penile complex of a stage 3 CApp (10-months old female); which includes the penile bulb and the muscular region of the penis, both enclosed in the penile sac; the penile complex papilla is in the groove which separates the penile complex from the nearby rectum and the anal papilla. Abbreviations: hs, hemocoelic spaces of the penile complex papilla; pcp, penile complex papilla; mcd, mucus and cell debris; mph, hemocoel of the muscular penis; mpd, duct of the muscular penis; pbd, duct of the penile bulb; re, rectum. Bars: $A=250 \mu \mathrm{m}, \mathrm{B}=250 \mu \mathrm{m}$.

Littorinimorpha (Oehlmann et al., 1991; Shi et al., 2005; Titley-O'Neal et al., 2011). However, its adaptation to the peculiar copulatory organs of the Ampullariidae cannot be as straightforward, because homologs of the ampullariid copulatory structures cannot be traced in females of those clades.

In general, imposex in neogastropods develops as the sequential neoformation of a vas deferens and a penis on the right side of the neck, where these structures normally occur in adult males (Ponder and Lindberg, 1997).

In their adaptation of the VDSI to $M$. cornuarietis, (SchulteOehlmann et al., 1995, 1994) considered the first part of the penile duct of this snail (contained within the penile bulb) as a homolog to the distal vas deferens in imposex-affected neogastropods. However, thorough comparative studies have not shown any homolog of a distal vas deferens in the Ampullariidae (Berthold, 1991; Simone, 2004) and Gamarra-Luques et al. (2013) showed that the CApp of $P$. canaliculata (including the entire penile duct) arise from a primordium different from that of the gonoduct, so it should be concluded that the penile duct in the Ampullariidae is not a homolog of the distal vas deferens of other Caenogastropoda.

It should be said that this does not invalidate to any extent the results obtained with this adaptation of the VDSI (Duft et al., 2007; Oehlmann et al., 2000; Schulte-Oehlmann et al., 1995, 1994, 2004, 2000; Tillmann et al., 2001; Weltje and Schulte-Oehlmann, 2007); they just imply that the index defined by Schulte-Oehlmann et al. (1994) for M. cornuarietis contains a misnomer based on a wrong homology and that this mistake may lead to wrong comparative conclusions.

On the contrary, the VDSI defined by Liu et al. and Wu et al., (2006, 2010) on P. canaliculata and P. scalaris was based on several anatomical misidentifications and inconsistencies, namely: the term 'rudimentary penis' was applied to either the entire rudimentary CApp (Liu et al., 2006, their Fig. 3A, and Wu et al., 2010, their Fig. 3B), to the penile pouch containing the penis (Liu et al., 2006, their Fig. 3B, and Wu et al., 2010, their Fig. 3C), or to the emptied penile pouch after unthreading the penis (Liu et al., 2006, their Fig. 3C, and Wu et al., 2010, their Fig. 3D). Indeed, these anatomical mistakes cast doubts on the validity of their observations and conclusions (as will be discussed in Section 4.3).

\subsection{A developmental index for $P$. canaliculata}

The DI used here was based on constituents of the female CApp that were precisely defined by Gamarra-Luques et al. (2013) and which can be recognized both in fresh and properly fixed material under a stereoscopic microscope.

This DI defined for $P$. canaliculata does not rely on the development of the penile complex papilla, whose homolog in M. cornuarietis (referred to as 'vas deferens papilla') characterizes 'stage 3' of the VDSI defined by Schulte-Oehlmann et al. (1994) for this species. In fact, this small structure seems always present in the CApp of female $P$. canaliculata, even in 'stage 1', but it may be hidden within the groove separating the CApp from the rectum, and may be many times covered by mucus and cellular debris, so that is not a useful character to evaluate female masculinization in this species. Preliminary observations (Giraud-Billoud \& Castro-Vazquez, unpublished) suggest it is the female homolog of the mucosal flap closing the 'sperm pit' in the male CApp (Andrews, 1964; Berthold, 1991).

\subsection{The use of the 'percent index of imposex' (\%I) and other parameters of masculinization in $P$. canaliculata and $P$. scalaris}

The \%I has been the most frequently used parameter for evaluating female masculinization in a variety of gastropods, including representatives of the Neogastropoda, Vetigastropoda, and Littorinimorpha (Titley-O'Neal et al., 2011), whose females do not normally show a CApp. However, if one considers the normal occurrence of a CApp as 'natural imposex', as some have done (see TitleyO'Neal et al., 2011) the \%I in ampullariid species would always be $100 \%$. Accordingly, it was stated in one of those papers (SchulteOehlmann et al., 1994; p. 74) that an organotin compound 'cannot cause the induction of imposex' in the ampullariid $M$. cornuarietis, though is however 'able to intensify the degree of female masculinization'.

Notwithstanding the numerous reports of the occurrence of the CApp in female Ampullariidae (see Introduction), both Liu et al. (2006) and Wu et al. (2010) have attributed to TBT contamination the 'high incidence of imposex' (i.e., high \%I) in $P$. canaliculata and $P$. scalaris from several Taiwan locations. Indeed, the actual conflict with the literature lies in their report of numerous cases with no CApp (their 'stage 0 ', which were up to $100 \%$ in some of their samples). Besides the already noted anatomical inconsistencies in those papers (see 4.1), which make their observations uncertain, it should be noted they have frozen their samples for later observation, and that the dehydration and flattening caused by freezing and thawing may have hampered the recognition of the lesser developed apparatuses and may have led to misdiagnoses.

Other parameters to assess female masculinization, such as the length of the penis and the penile sheath, were also determined in the 

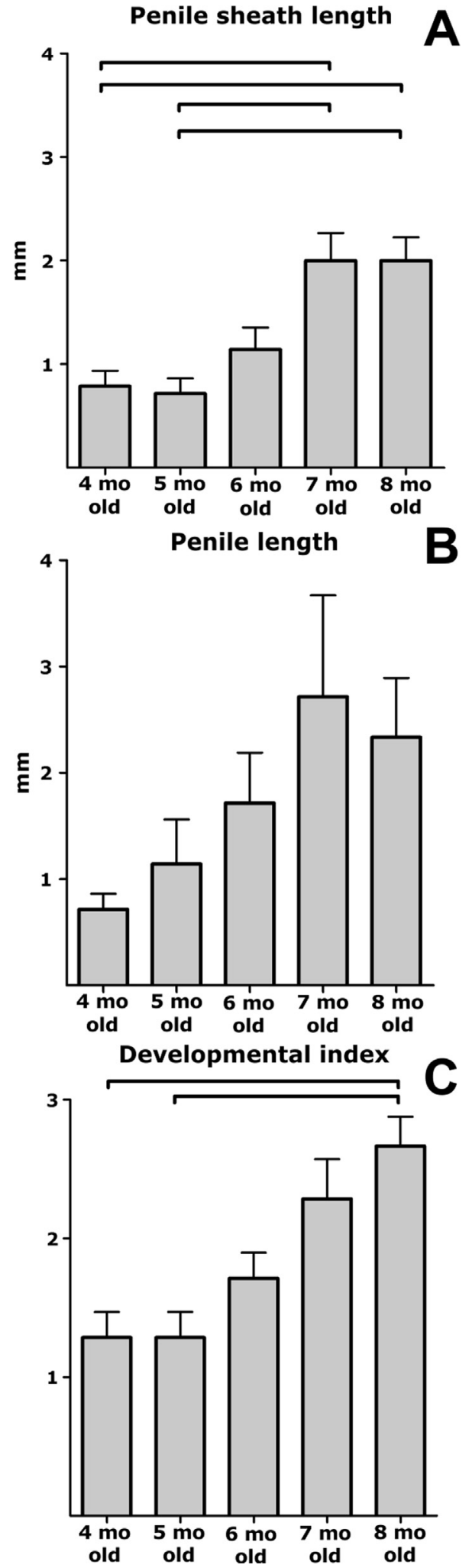

Fig. 3. Effect of age on the development of the female CApp. Horizontal brackets indicate statistically significant differences $(P<0.05$, Kruskal-Wallis test, Dunn test).

current report. In all cases, changes in the penile sheath correlated well with those of the DI, but changes in the penile length were less reliable, particularly when small changes were involved. This is probably related to the tendency to coil and retract of this organ.

\subsection{The influence of age on the development of the female CApp}

Gamarra-Luques et al. (2013) have indicated that the female CApp may continue its development and growth in $P$. canaliculata after sexual maturity, i.e., which is reached at $25 \mathrm{~mm}$ in shell length and 50 days old. In the current study, 4-8 months old females were studied, i.e., approximating the life period of a female born in early spring and which stops reproduction or dies in the following fall or winter. In Argentina, the southernmost populations of this species may show up to 3-4 annual reproductive periods, but much shorter lifespans (about one year) are expected to occur in tropical or subtropical regions where this species becomes semelparous (Estebenet and Martín, 2002; Hayes et al., 2015). Fig. 3 shows an initially sustained increase in the DI and the length of the penile sheath, with a tendency to stabilize after 7 months of age. These changes of the female CApp with age suggest that the observations of 'imposex' in the field (Liu et al., 2006; Wu et al., 2010) may be just indicating a higher proportion of older females in the population, rather than organotin pollution.

It has been shown that TBT exposure to the $\mathrm{NOEC}_{\mathrm{L}}$ in water definitely promotes the development and growth of the CApp in female $P$. canaliculata (Giraud-Billoud et al., 2013b). Also, it has recently been shown that TBT, and its metabolites DBT and MBT, accumulate in several tissues of $P$. canaliculata following a 6-months exposure to an environmentally relevant concentration of TBT (Martínez et al., 2017). The latter study was not aimed at determining changes in the CApp and therefore no quantification was attempted. However, the authors mentioned that all exposed females showed 'development of a penis', but did not mention the status of the CApp in controls. Since females in their exposure experiment were 10-11 months old at sacrifice, it should be expected that both control and exposed snails had significant developments of the CApp. So, until now, it may be said that organotins may be valuable experimental tools to explore the trophic mechanisms (Gamarra-Luques et al., 2006) involved in the growth of the CApp in this species and the development of CApp should not be used as a useful indicator of organotin pollution when the age of the field-collected individuals is unknown.

\subsection{Differential effects of organotins (TBT, TPT) and of RXR and PPAR $\gamma$ agonists on the female CApp}

Both the endogenous RXR ligand 9cis-RA and the organotins TBT and TPT have here been shown to promote female masculinization in $P$. canaliculata.

Three main lines of evidence regarding the mechanisms of organotin masculinization of female gastropods have been followed up: (1) evidence for a role of androgenic and estrogenic substances (e.g., Bettin et al., 1996; Gooding et al., 2003; Janer et al., 2006; Oehlmann et al., 2000; Ronis and Mason, 1996; Schulte-Oehlmann et al., 2004; Spooner et al., 1991; Tillmann et al., 2001); (2) evidence for a neurotoxic action and involvement of the neuropeptide APGWamide (Oberdorster and McClellan-Green, 2002, 2000; Oberdörster et al., 2005); and more recently, (3) evidence for the involvement of nuclear receptors, including RXR (Castro et al., 2007; Horiguchi et al., 2007, 2010, 2008; Nishikawa et al., 2004; Sousa et al., 2010; Stange et al., 2012) and the peroxisome proliferator-activated receptors (PPAR) (Pascoal et al., 2013; Pascoal, 2011).

The possible role of RXR and PPAR agonists had not been explored before in ampullariid gastropods. In the current paper, three reported agonists of the RXR (9cis-RA, TBT and TPT) clearly promoted the development and growth of the female CApp in $P$. canaliculata. In addition, 9cis-RA selectively increased the expression of the RXR in the female CApp of this species, which is the first record of such an in vivo action of this compound in gastropods. Notwithstanding, TBT was only followed by a small and statistically non-significant increase, while TPT showed no effect in the same experiment. Recently, Urushitani et al. (2018) have used an in vitro assay of whole soft tissues from three 

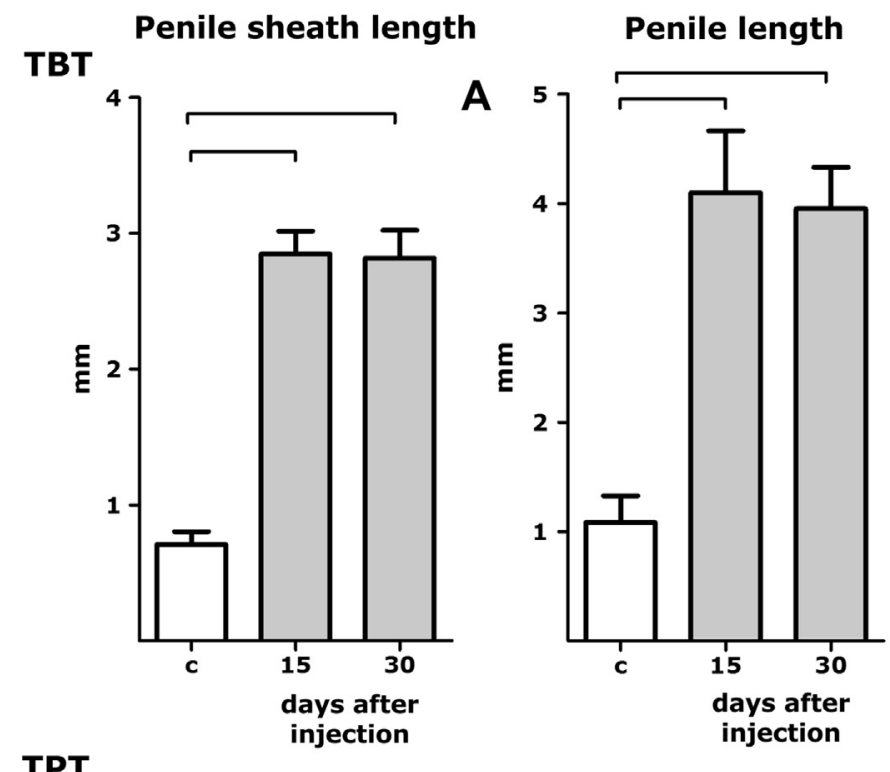

Developmental index

TPT

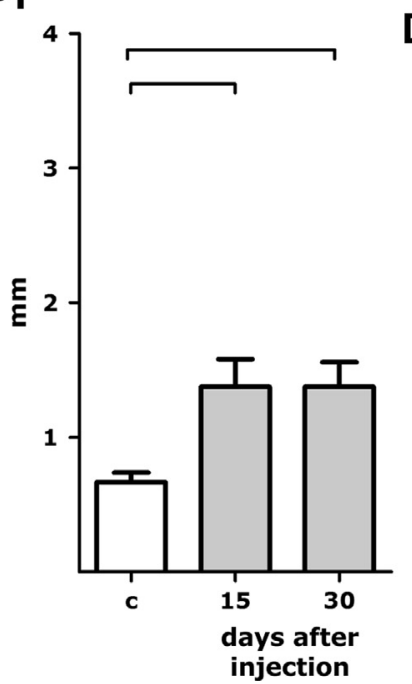

D

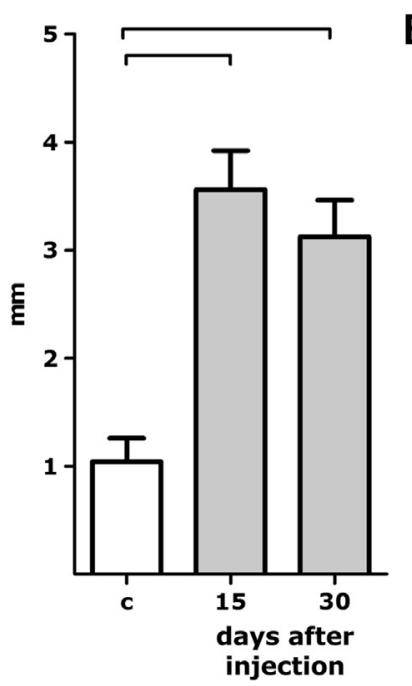

B

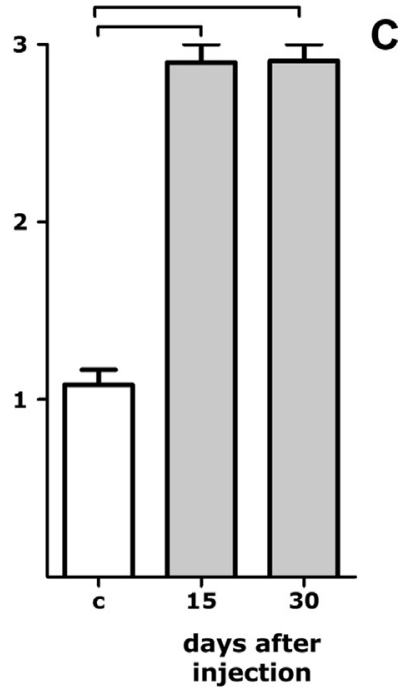

E

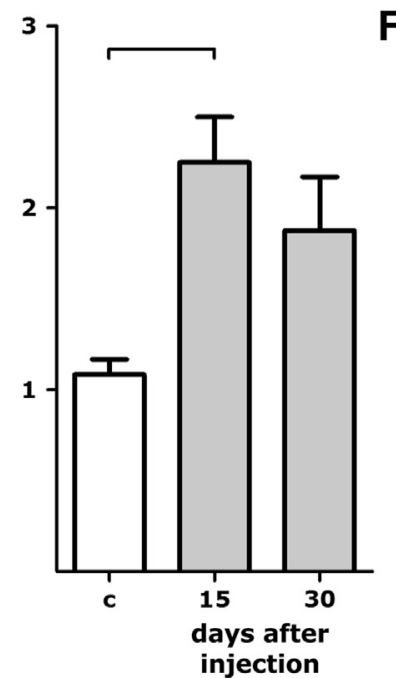

Fig. 4. Effects of a single injection of TBT (upper panel) or TPT (lower panel) to 4-months old females. Bars represent means \pm SEM, white bars represent females injected with vehicle, while gray bars represent females injected with $1 \mu \mathrm{g}$ of each organotin compound per g of drained body mass. Horizontal brackets indicate statistically significant differences $(P<0.05$, Kruskal-Wallis test, Dunn test).

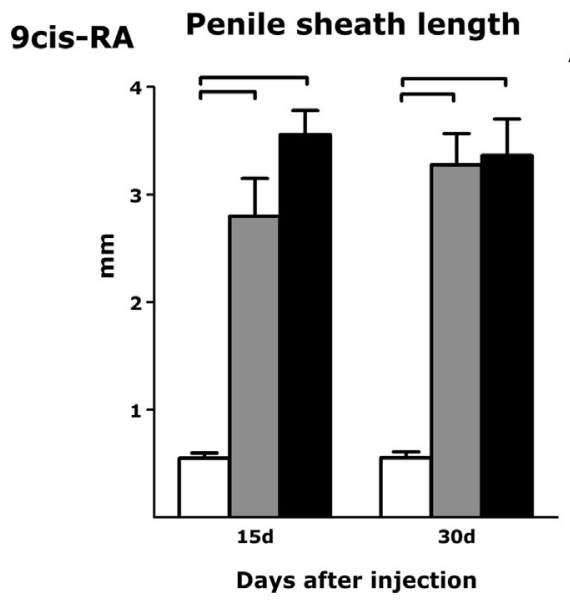

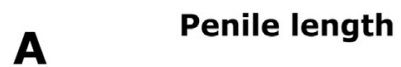

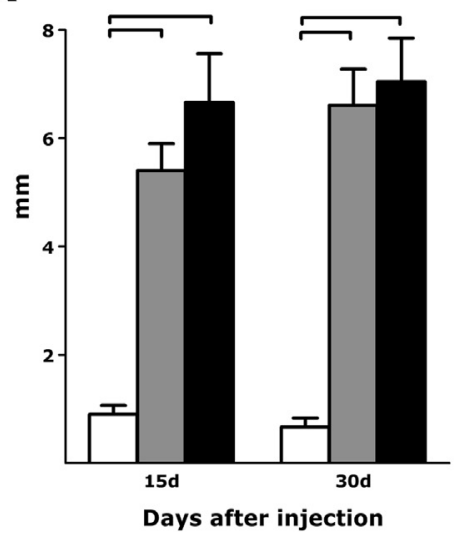

B Developmental index

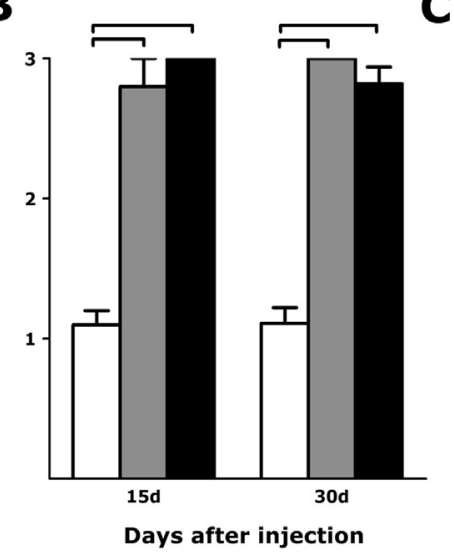

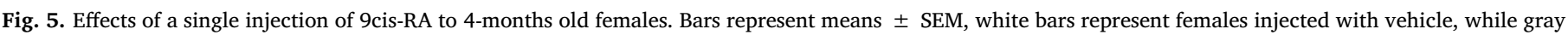

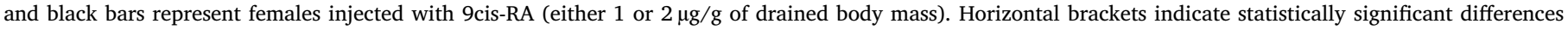
( $P<0.05$, Kruskal-Wallis test, Dunn test). 

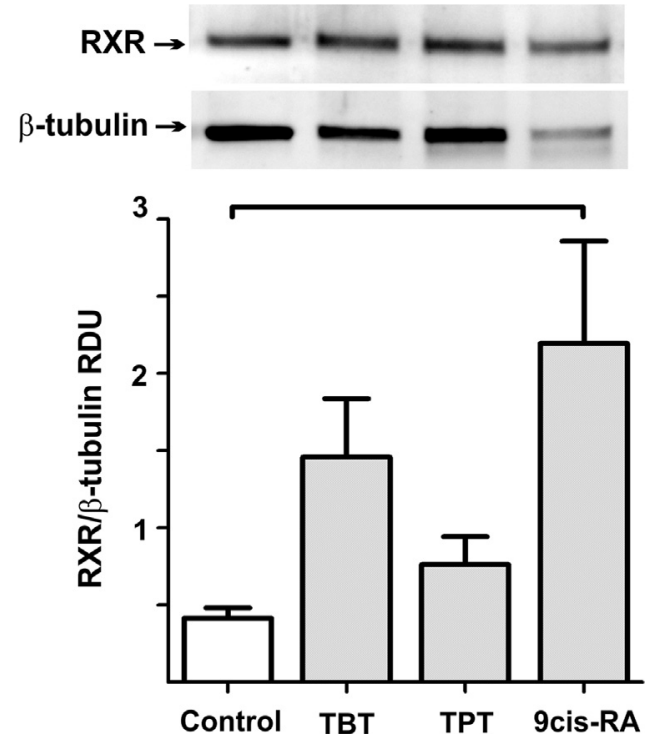

Fig. 6. RXR expression in 4-months old females, $2 \mathrm{~h}$ after injection of vehicle or of $1 \mu \mathrm{g} / \mathrm{g}$ drained body mass of either TBT, TPT or 9cis-RA. Bars represent means \pm SEM. $(P<0.05$, one-way ANOVA, Tukey test).

neogastropod species (Thais clavigera, Nucella lapillus, and Babylonia japonica) and found significant increases of transcriptional activities of RXR isoforms, in response to 9cis-RA and several organotin compounds (including TBT and TPT). However, although the masculinizing effect of both 9cis-RA and TBT exposition has been documented in a variety of gastropods (Titley-O'Neal et al., 2011), a correlative masculinizing effect of TPT is not as clear, because no penile growth has been reported in N. lapillus after TPT exposition or injection (Bryan et al., 1988; Schulte-Ohhlmann et al., 2000; Laranjeiro et al., 2016). As mentioned above, TPT promoted female masculinization in the current study, but it did not induce any change in RXR expression. It should be considered, however, that this does not necessarily imply that these organotins are not exerting their masculinizing actions through the RXR signaling pathway, because it is possible that the timing of the responses was different.

Nevertheless, the administration of a PPAR $\gamma$ agonist (Roz), which has been shown to induce imposex in the neogastropod $N$. lapillus (Pascoal, 2011), was clearly ineffective to promote masculinization in $P$. canaliculata. This difference may be explained by the fact that the target tissues for masculinizing substances are different in ampullariid and neogastropod species, and therefore may involve different molecular mechanisms. Among the latter, it should be mentioned that even the existence of the $\gamma$-subtype of PPAR has been questioned in another, though phylogenetically distant gastropod (Biomphalaria glabrata, Planorbidae, Panpulmonata, Kaur et al., 2015).

Also, many studies have been prompted by the discovery of an obesogenic (adipogenic) effect of organotins in vertebrates (Grün and Blumberg, 2006; Grün et al., 2006). These studies have shown that TBT is a strong agonist of RXRa (le Maire et al., 2009) while both TBT and TPT are strong agonists of PPAR $\gamma$ (Hiromori et al., 2009) and the transactivation of RXR $\alpha / \operatorname{PPAR} \gamma$ could exert a synergistic effect (Hiromori et al., 2015). It has also been shown that RXR interacts with PPARs and a variety of other nuclear receptors, which includes dimerization, transactivation and synergistic actions between their signaling pathways (Brtko and Dvorak, 2015). Thus, the lack of effect of Roz reported here may also be explained by a lack of a simultaneous activation of the RXR signaling pathway. Unfortunately, this could not be tested in the experimental approach of the current study, since RXR agonists already had a near-maximal effect on female masculinization. However, the role of nuclear receptors in the development of masculinity traits should be explored further, particularly after the development of new tools for such purposes (e.g., Ip et al., 2018).

Although the obesogenic effect of organotins cannot have a parallel in gastropods, because they lack a specialized adipose tissue (Vague and Fenasse, 2010), their fundamental molecular mechanisms may even be present in the copulatory organs of gastropods, and they deserve to be studied.

\section{Conclusions}

Development and growth of the CApp increase significantly with age in $P$. canaliculata, and therefore, it should be emphasized that organotin contamination cannot be inferred from field studies of masculinization, in which the age of the collected Pomacea individuals is unknown.

Also, both the penile sheath length and a DI (as defined in this paper) were useful to quantify the degree of female masculinization in this species. These measurements showed that RXR agonists (9cis-RA, TBT and TPT) but not the PPAR $\gamma$ agonist (Roz), promoted masculinization in $P$. canaliculata.

Furthermore, the expression of RXR in the CApp was upregulated by 9cis-RA, but no significant effects of TBT or TPT were observed. However, the known multiple interactions of nuclear receptors signaling and the increased knowledge of ampullariid genomics all stress the need of studying the molecular mechanisms underlying the development of properly defined masculinity traits, both in females and males of this and other congeneric species.

\section{Acknowledgments}

This work was supported by grants from Fondo para la Investigación Científica y Tecnológica [FONCyT, PICT-2013-1190] to A. CastroVazquez and from Universidad Nacional de Cuyo (SECTyP, RCS05712015, to I. A. Vega and SECTyP, J064, to M. Giraud-Billoud).

\section{Appendix A. Supporting information}

Supplementary data associated with this article can be found in the online version at doi:10.1016/j.ecoenv.2018.10.096.

\section{References}

Aboul-Ela, I., Beddiny, E., 1970. On the reproductive processes and the development of Lanistes bolteni Chemnitz, 1786. Ain Shams Sci. Bull. 177-221.

Andrews, E., 1964. The functional anatomy and histology of the reproductive system of some pilid gastropod molluscs. Proc. Malac. Soc. Lond. 36, 121-140. https://doi.org/ 10.1093/oxfordjournals.mollus.a064939.

Andrews, E., 1965. The functional anatomy of the mantle cavity, kidney and blood system of some pilid gastropods (Prosobranchia). J. Zool. 146, 70-94. https://doi.org/10. 1111/j.1469-7998.1965.tb05201.x.

Berthold, T., 1989. Comparative conchology and functional morphology of the copulatory organ of the Ampullariidae (Gastropoda, Monotocardia) and their bearing upon phylogeny and palaeontology. Abh nat Ver Hambg. 28, 141-164.

Berthold, T., 1991. Vergleichende anatomie, phylogenie und historische biogeographie der Ampullariidae (Mollusca, Gastropoda). Abh nat Ver Hambg. 29, 1-256.

Bettin, C., Oehlmann, J., Stroben, E., 1996. TBT-induced imposex in marine neogastropods is mediated by an increasing androgen level. Helgol. Mar. Res. 50, 299-317. https://doi.org/10.1007/BF02367105.

Bouchet, P., Rocroi, J.-P., 2005. Classification and nomenclator of gastropod families. Malacologia 47 (1-2), 1-397.

Brtko, J., Dvorak, Z., 2015. Triorganotin compounds-ligands for "rexinoid" inducible transcription factors: Biological effects. Toxicol. Lett. 234, 50-58. https://doi.org/10. 1016/j.toxlet.2015.02.009.

Bryan, G., Gibbs, P., Burt, G., 1988. A comparison of the effectiveness of tri-n-butyltin chloride and five other organotin compounds in promoting the development of imposex in the dog-whelk, Nucella lapillus. J. Mar. Biol. Assoc. U.K. 68, 733-744. https://doi.org/10.1017/S0025315400028836.

Bouvier, E., 1888. Étude sur l'organisation des Ampullaires. Mem. Soc. Philom. 63-85.

Castro, L.F.C., Lima, D., Machado, A., Melo, C., Hiromori, Y., Nishikawa, J., Nakanishi, T., Reis-Henriques, M., Santos, M., 2007. Imposex induction is mediated through the Retinoid X Receptor signalling pathway in the neogastropod Nucella lapillus. Aquat. Toxicol. 85, 57-66. https://doi.org/10.1016/j.aquatox.2007.07.016.

Cueto, J.A., Rodriguez, C., Vega, I.A., Castro-Vazquez, A., 2015. Immune defenses of the invasive apple snail Pomacea canaliculata (Caenogastropoda, Ampullariidae): 
phagocytic hemocytes in the circulation and the kidney. PLoS One 10, e0123964. https://doi.org/10.1371/journal.pone.0123964.

Cheng, E.Y., Kao, C., 2006. Control of golden apple snail, Pomacea canaliculata (Lamarck), in Taiwan. In: Joshi, R.C., Sebastian, L.S. (Eds.), Global Advances In Ecology And Management Of Golden Apple Snails. Philippine Rice Research Institute, Nueva Ecija, pp. 155-167.

Duft, M., Schmitt, C., Bachmann, J., Brandelik, C., Schulte-Oehlmann, U., Oehlmann, J., 2007. Prosobranch snails as test organisms for the assessment of endocrine active chemicals-an overview and a guideline proposal for a reproduction test with the freshwater mudsnail Potamopyrgus antipodarum. Ecotoxicology 16, 169-182. https:// doi.org/10.1007/s10646-006-0106-0.

Estebenet, A., Martín, P., 2002. Pomacea canaliculata (Gastropoda: Ampullariidae): lifehistory traits and their plasticity. Biocell 26, 83-89.

Gamarra-Luques, C., Winik, B.C., Vega, I.A., Albrecht, E.A., Catalan, N.M., CastroVazquez, A., 2006. An integrative view to structure, function, ontogeny and phylogenetical significance of the male genital system in Pomacea canaliculata (Caenogastropoda, Ampullariidae). Biocell 30, 345-357.

Gamarra-Luques, C., Giraud-Billoud, M., Castro-Vazquez, A., 2013. Reproductive organogenesis in the apple snail Pomacea canaliculata (Lamarck, 1822), with reference to the effects of xenobiotics. J. Molluscan Stud. 79, 147-162. https://doi.org/10.1093/ mollus/eyt011.

Gand, P.P., 1896. L'hermaphroditisme chez les Mollusques. Arch. Biol. 14, 33.

Gibbs, P.E., Bryan, G., Pascoe, P., Burt, G., 1987. The use of the dog-whelk, Nucella lapillus, as an indicator of tributyltin (TBT) contamination. J. Mar. Biolog. Assoc. 67, 507-523. https://doi.org/10.1017/S0025315400027260.

Giraud-Billoud, M., Abud, M.A., Cueto, J.A., Vega, I.A., Castro-Vazquez, A., 2011. Uric acid deposits and estivation in the invasive apple-snail, Pomacea canaliculata. Comp. Biochem. Physiol. Part A Mol. Integr. Physiol. 158, 506-512. https://doi.org/10. 1016/j.cbpa.2010.12.012.

Giraud-Billoud, M., Vega, I.A., Wuilloud, R.G., Clément, M.E., Castro-Vazquez, A., 2013a. Imposex and novel mechanisms of reproductive failure induced by tributyltin (TBT) in the freshwater snail Pomacea canaliculata. Environ. Toxicol. Chem. 32, 2365-2371. https://doi.org/10.1002/etc.2310.

Giraud-Billoud, M., Gamarra-Luques, C., Castro-Vazquez, A., 2013b. Functional anatomy of male copulatory organs of Pomacea canaliculata (Caenogastropoda, Ampullariidae). Zoomorphology 132, 129-143. https://doi.org/10.1007/s00435012-0183-y.

Gooding, M.P., Wilson, V.S., Folmar, L.C., Marcovich, D.T., LeBlanc, G.A., 2003. The biocide tributyltin reduces the accumulation of testosterone as fatty acid esters in the mud snail (Ilyanassa obsoleta). Environ. Health Perspect. 111 (426) https:// doi:10.1289/ehp.5779.

Greene, S.A., Pohanish, R.P., 2005. Sittig's Handbook of Pesticides and Agricultural Chemicals. William Andrew.

Grün, F., Blumberg, B., 2006. Environmental obesogens: organotins and endocrine disruption via nuclear receptor signaling. Endocrinology 147, s50-s55. https://doi.org/ 10.1210/en.2005-1129.

Grün, F., Watanabe, H., Zamanian, Z., Maeda, L., Arima, K., Cubacha, R., Gardiner, D., Kanno, J., Iguchi, T., Blumberg, B., 2006. Endocrine-disrupting organotin compounds are potent inducers of adipogenesis in vertebrates. Mol. Endocrinol. 20, 2141. https://doi.org/10.1210/me.2005-0367.

Hägler, K., 1923. Anatomie von Pachylabra (Ampullaria) cinerea Reeve: I. Teil. Mit Einschluss einer kurzen Besprechung der wichstigen Literatur über die Ampullariidae. Acta Zool. 4, 313-424.

Hayes, K., Burks, R., Castro-Vazquez, A., Darby, P., Heras, H., Martín, P., Qiu, J.-W., Thiengo, S., Wada, T., Yusa, Y., Burela, S., Cadierno, M.P., Cueto, J., Dellagnola, F., Dreon, M., Frassa, M., Giraud-Billoud, M., Godoy, M., Ituarte, S., Koch, E., Matsukura, K., Pasquevich, M., Rodriguez, C., Saveanu, L., Seuffert, M., Strong, E., Sun, J., Tamburi, N.E., Tiecher, M., Turner, R., Valentine-Darby, P., Vega, I., Cowie, R., 2015. Insights from an integrated view of the biology of apple snails (Caenogastropoda: Ampullariidae). Malacologia 58, 245-302. https://doi.org/10.4002/040.058.0209.

Hayes, K.A., Cowie, R.H., Thiengo, S.C., Strong, E.E., 2012. Comparing apples with apples: clarifying the identities of two highly invasive Neotropical Ampullariidae (Caenogastropoda). Zool. J. Linn. Soc. 166, 723-753. https://doi.org/10.1111/j. 1096-3642.2012.00867.x.

Hiromori, Y., Aoki, A., Nishikawa, J.-i, Nagase, H., Nakanishi, T., 2015. Transactivation of the human retinoid $\mathrm{X}$ receptor by organotins: use of site-directed mutagenesis to identify critical amino acid residues for organotin-induced transactivation. Metallomics 7, 1180-1188. https://doi.org/10.1039/C5MT00086F.

Hiromori, Y., Nishikawa, J.-i, Yoshida, I., Nagase, H., Nakanishi, T., 2009. Structure-dependent activation of peroxisome proliferator-activated receptor (PPAR) [gamma] by organotin compounds. Chem. Biol. Interact. 180, 238-244. https://doi.org/10.1016/ j.cbi.2009.03.006.

Horiguchi, T., Nishikawa, T., Ohta, Y., Shiraishi, H., Morita, M., 2007. Retinoid X receptor gene expression and protein content in tissues of the rock shell Thais clavigera. Aquat. Toxicol. 84, 379-388. https://doi.org/10.1016/j.aquatox.2007.06.019.

Horiguchi, T., Ohta, Y., Nishikawa, T., Shiraishi, F., Shiraishi, H., Morita, M., 2008. Exposure to 9-cis retinoic acid induces penis and vas deferens development in the female rock shell Thais clavigera. Cell Biol. Toxicol. 24, 553-562. https://doi.org/10. 1007/s10565-007-9051-9.

Horiguchi, T., Nishikawa, T., Ohta, Y., Shiraishi, H., Morita, M., 2010. Time course of expression of the retinoid $\mathrm{X}$ receptor gene and induction of imposex in the rock shell Thais clavigera exposed to triphenyltin chloride. Anal. Bioanal. Chem. 396, 597-607. https://doi.org/10.1007/s00216-009-3230-x.

Horiguchi, T., 2016. Biological Effects by Organotins. . Springer https://doi.org/10.1007/ 978-4-431-56451-5.

Hylton-Scott, M., 1958. Estudio morfológico y taxonómico de los ampulláridos de la
República Argentina. Revista Museo Argentino Ciencias Naturales 3, 233-333. Hyman, L.H., 1967. The Invertebrates. McGraw-Hill, New York.

IMO, 2000. International maritime organisation agrees ban on tributyltin (TBT). Propeller 7, 2-3.

Ip, J.C., Mu, H., Chen, Q., Sun, J., Ituarte, S., Heras, H., Van Bocxlaer, B., Ganmanee, M., Huang, X., Qiu, J.-W., 2018. AmpuBase: a transcriptome database for eight species of apple snails (Gastropoda: Ampullariidae). BMC Genom. 19, 179. https://doi.org/10. 1186/s12864-018-4553-9.

Janer, G., Lyssimachou, A., Bachmann, J., Oehlmann, J., Schulte-Oehlmann, U., Porte, C., 2006. Sexual dimorphism in esterified steroid levels in the gastropod Marisa cornuarietis: the effect of xenoandrogenic compounds. Steroids 71, 435-444. https://doi. org/10.1016/j.steroids.2006.01.012.

Kaur, S., Jobling, S., Jones, C.S., Noble, L.R., Routledge, E.J., Lockyer, A.E., 2015. The nuclear receptors of Biomphalaria glabrata and Lottia gigantea: implications for developing new model organisms. PLoS One 10, e0121259. https://doi.org/10.1371/ journal.pone.0121259.

le Maire, A., Grimaldi, M., Roecklin, D., Dagnino, S., Vivat-Hannah, V., Balaguer, P., Bourguet, W., 2009. Activation of RXR-PPAR heterodimers by organotin environmental endocrine disruptors. EMBO Rep. 10, 367-373. https://doi.org/10.1038/ embor.2009.8.

Liu, W., Chiu, Y., Huang, D., Liu, M., Lee, C., Liu, L., 2006. Imposex in the golden apple snail Pomacea canaliculata in Taiwan. Sci. Total Environ. 371, 138-143. https://doi. org/10.1016/j.scitotenv.2006.08.037.

Lowry, O.H., Rosebrough, N.J., Farr, A.L., Randall, R.J., 1951. Protein measurement with the Folin phenol reagent. J. Biol. Chem. 193, 265-275.

Martínez, M.L., Piol, M.N., Nudelman, N.S., Guerrero, N.R.V., 2017. Tributyltin bioaccumulation and toxic effects in freshwater gastropods Pomacea canaliculata after a chronic exposure: field and laboratory studies. Ecotoxicology 1-11. https://doi.org/ 10.1007/s10646-017-1801-8.

Nishikawa, J., Mamiya, S., Kanayama, T., Nishikawa, T., Shiraishi, F., Horiguchi, T., 2004. Involvement of the retinoid $X$ receptor in the development of imposex caused by organotins in gastropods. Environ. Sci. Technol. 38, 6271-6276. https://doi.org/ 10.1021/es049593u.

Oberdörster, E., McClellan-Green, P., 2000. The neuropeptide APGWamide induces imposex in the mud snail. Ilyanassa Obsoleta Pept. 21, 1323-1330. https://doi.org/10. 1016/S0196-9781(00)00274-6.

Oberdorster, E., McClellan-Green, P., 2002. Mechanisms of imposex induction in the mud snail, Ilyanassa obsoleta: TBT as a neurotoxin and aromatase inhibitor. Mar. Environ. Res. 54, 715-718. https://doi.org/10.1016/S0141-1136(02)00118-6.

Oberdörster, E., Romano, J., McClellan-Green, P., 2005. The neuropeptide APGWamide as a penis morphogenic factor (PMF) in gastropod mollusks. Integr. Comp. Biol. 45, 28-32. https://doi.org/10.1093/icb/45.1.28.

Oehlmann, J., Stroben, E., Fioroni, P., 1991. The morphological expression of imposex in Nucella lapillus (Linnaeus)(Gastropoda: Muricidae). J. Molluscan Stud. 57, 375-390. https://doi.org/10.1093/mollus/57.3.375.

Oehlmann, J., Schulte-Oehlmann, U., Tillmann, M., Markert, B., 2000. Effects of endocrine disruptors on prosobranch snails (Mollusca: Gastropoda) in the laboratory. Part I: Bisphenol A and octylphenol as xeno-estrogens. Ecotoxicology 9, 383-397. https:// doi.org/10.1023/A:1008972518019.

Pascoal, S., 2011. Nucella lapillus: imposex transcriptome analysis and phenotypic plasticity. Ph.D. Thesis. Universidade de Aveiro (Portugal), ProQuest Dissertations Publishing, 2011. 10590977.

Pascoal, S., Carvalho, G., Vasieva, O., Hughes, R., Cossins, A., Fang, Y., Ashelford, K., Olohan, L., Barroso, C., Mendo, S., Creer, S., 2013. Transcriptomics and in vivo tests reveal novel mechanisms underlying endocrine disruption in an ecological sentinel. Nucella lapillus Mol. Ecol. 22, 1589-1608. https://doi.org/10.1111/mec.12137.

Ordenanza No, P.N.A., 1998. 4/98 de la Prefectura Naval Argentina. Régimen para la protección del medioambiente. Buenos Aires, Argentina.

Ponder, W.F., Lindberg, D.R., 1997. Towards a phylogeny of gastropod molluscs: an analysis using morphological characters. Zool. J. Linn. Soc. 119, 83-265. https://doi. org/10.1111/j.1096-3642.1997.tb00137.x.

Prashad, B., 1925. Anatomy of the common Indian apple-snail. Pila globosa. Rec Zool Surv India.

Ronis, M., Mason, A., 1996. The metabolism of testosterone by the periwinkle (Littorina littorea) in vitro and in vivo: effects of tributyl tin. Mar. Environ. Res. 42, 161-166. https://doi.org/10.1016/0141-1136(95)00069-0.

Sachwatkin, V., 1920. Das Urogenitalsystem von Ampullaria gigas Spix. Acta Zool. 1, 67-130.

Schulte-Oehlmann, U., Fioroni, P., Oehlmann, J., Stroben, E., 1994. The genital system of Marisa cornuarietis (Gastropoda, Ampullariidae): a morphological and histological analysis. Bonn. Zool. Beitr. 36, 59-81.

Schulte-Oehlmann, U., Bettin, C., Fioroni, P., Oehlmann, J., Stroben, E., 1995. Marisa cornuarietis (Gastropoda, prosobranchia): a potential TBT bioindicator for freshwater environments. Ecotoxicology 4, 372-384. https://doi.org/10.1007/BF00118872.

Schulte-Oehlmann, U., Tillmann, M., Markert, B., Oehlmann, J., Watermann, B., Scherf, S., 2000. Effects of endocrine disruptors on prosobranch snails (Mollusca: Gastropoda) in the laboratory. Part II: Triphenyltin as a xeno-androgen Ecotoxicology 9, 399-412. https://doi.org/10.1023/A:1008924602089.

Schulte-Oehlmann, U., Oetken, M., Bachmann, J., Oehlmann, J., 2004. Effects of ethinyloestradiol and methyltestosterone in prosobranch snails: pharmaceuticals in the Environment. Springer, pp. 233-247 https://doi.org/10.1007/978-3-662-09259$0 \_19$.

Semper, K., 1862. Entwickelungsgeschichte der Ampullaria polita Deshayes, nebst Mittheilungen über die Entwickelungsgeschichte einiger andern Gastropoden aus den Tropen. C. van der Post Jr.

Shi, H., Huang, C., Zhu, S., Yu, X., Xie, W., 2005. Generalized system of imposex and 
reproductive failure in female gastropods of coastal waters of mainland China. Mar. Ecol. Prog. Ser. 304, 179-189.

Simone, L., 2004. Comparative morphology and phylogeny of representatives of the superfamilies of Architaenioglossans and the Annulariidae (Mollusca, Caenogastropoda). Arq. Mus. Nac. 62, 387-504.

Sousa, A., Barroso, C., Tanabe, S., Horiguchi, T., 2010. Involvement of Retinoid X Receptor in Imposex Development in Nucella lapillus and Nassarius reticulatus Preliminary Results. Interdiscip. Stud. Environ. Chem. Biol. Responses Contam. 3, 189-196.

Spooner, N., Gibbs, P., Bryan, G., Goad, L., 1991. The effect of tributyltin upon steroid titres in the female dogwhelk, Nucella lapillus, and the development of imposex. Mar. Environ. Res. 32, 37-49. https://doi.org/10.1016/0141-1136(91)90032-4.

Stange, D., Sieratowicz, A., Oehlmann, J., 2012. Imposex development in Nucella lapillus evidence for the involvement of retinoid $\mathrm{X}$ receptor and androgen signalling pathways in vivo. Aquat. Toxicol. 106-107, 20-24. https://doi.org/10.1016/j.aquatox. 2011.10.010.

Takao, Y., 2017. Biological effects by organotins. Continuing Issues of Contamination by Organotins in the Marine Environment After Domestic and International Legislation. Springer, pp. 27-41 https://doi.org/10.1007/978-4-431-56451-5_2.

Thiengo, S., 1987. Observations on the morphology of Pomacea lineata (Spix, 1827) (Mollusca, Ampullariidae). Mem. Inst. Oswaldo Cruz. 82, 563-570. https://doi.org/ 10.1590/S0074-02761987000400015.

Thiengo, S., 1989. On Pomacea sordida (Swainson, 1823) (Prosobranchia, Ampullariidae). Mem. Inst. Oswaldo Cruz. 84, 351-355. https://doi.org/10.1590/S0074 02761989000300009.
Thiengo, S., Borda, C., Araújo, J., 1993. On Pomacea canaliculata (Lamarck, 1822) (Mollusca; Pilidae: Ampullariidae). Mem. Inst. Oswaldo Cruz. 88, 67-71. https://doi. org/10.1590/S0074-02761993000100011.

Tillmann, M., Schulte-Oehlmann, U., Duft, M., Markert, B., Oehlmann, J., 2001. Effects of endocrine disruptors on prosobranch snails (Mollusca: Gastropoda) in the laboratory. Part III: Cyproterone acetate and vinclozolin as antiandrogens. Ecotoxicology 10, 373-388. https://doi.org/10.1023/A:1012279231373.

Titley-O'Neal, C.P., Munkittrick, K.R., MacDonald, B.A., 2011. The effects of organotin on female gastropods. J. Environ. Monit. 13, 2360-2388. https://doi.org/10.1039/ C1EM10011D.

Urushitani, H., Katsu, Y., Kagechika, H., Sousa, A.C., Barroso, C.M., Ohta, Y., Shiraishi, H., Iguchi, T., Horiguchi, T., 2018. Characterization and comparison of transcriptional activities of the retinoid $\mathrm{X}$ receptors by various organotin compounds in three prosobranch gastropods; Thais clavigera, Nucella lapillus and Babylonia japonica. Aquatic Toxicol. 199, 103-115. https://doi.org/10.1016/j.aquatox.2018.03.029.

Vague, J., Fenasse, R., 2010. Comparative anatomy of adipose. Compr. Physiol. 5 (25-36), tissue1. https://doi.org/10.1002/cphy.cp050105.

Weltje, L., Schulte-Oehlmann, U., 2007. The seven year itch-progress in research on endocrine disruption in aquatic invertebrates since 1999. Ecotoxicology. 16, 1-3. https://doi.org/10.1007/s10646-006-0116-y.

WHO, 1999. Triphenyltin compounds. Concise International Chemical Assessment Document 40.

Wu, J., Meng, P., Liu, M., Chiu, Y., Liu, L., 2010. A high incidence of imposex in Pomacea Apple snails in Taiwan: a decade after triphenyltin was banned. Zool. Stud. 49, 85-93. 